\title{
Tumor necrosis factor- $\alpha$-activated mesenchymal stem cells accelerate wound healing through vascular endothelial growth factor regulation in rats
}

\author{
Aditya Nugraha* and Agung Putra**,***
}

\begin{abstract}
\section{BACKGROUND}

Wounds are areas of physical or thermal damage of the epithelial layer of skin or mucosa. The wound healing process consists of hemostasis, inflammation, proliferation, and remodeling. Mesenchymal stem cells (MSCs) play a role in wound healing by suppressing potent proinflammatory molecules, such as tumor necrosis factor- $\alpha$ (TNF- $\alpha$ ), leading to macrophage polarization from the pro-inflammatory type to the proregeneration type characterized by increasing vascular endothelial growth factor (VEGF) production. MSCs are able to increase VEGF level in-vivo correlated with collagen synthesis. The objective of this study was to assess the role of TNF- $\alpha$-activated MSCs on VEGF in rat wounds.
\end{abstract}

\section{METHODS}

An experimental animal study with post-test only control group design was performed involving 24 Wistar rats. The rats were randomized into four groups consisting of one control $(\mathrm{K})$ and three treatment groups $(\mathrm{P})$ (activated MSCs at doses of $3 \times 10^{5}, 6 \times 10^{5}$, and $12 \times 10^{5}$ cells, respectively). The measurement of VEGF levels was done using ELISA assay while the collagen analysis was performed by light microscopy. One way ANOVA and Post Hoc LSD were used to analyze the data.

\section{RESULTS}

The results showed a significant increase in VEGF levels $(p<0.05)$ on day 3 and then a significant decrease on day 5 along with a significant increase in the amount of collagen on day $7(\mathrm{p}<0.05)$.

\section{CONCLUSION}

This study demonstrated that TNF- $\alpha$-activated MSCs were able to regulate VEGF levels and collagen synthesis in wound healing in rats. The molecular mechanism by which TNF- $\alpha$-activated MSCs stimulate cutaneous wound healing should be clarified further.

Keywords: Mesenchymal stem cells, tumor necrosis factor- $\alpha$, vascular endothelial growth factor, collagen, rats
*Postgraduate Biomedical Program, Faculty of Medicine, Universitas Islam Sultan Agung, Semarang **Department of Postgraduate Biomedical Science, Faculty of Medicine, Universitas Islam Sultan Agung, Semarang

***Stem Cell and Cancer Research Laboratory (SCCR), Faculty of Medicine, Univeritas Islam Sultan Agung, Semarang

\section{Correspondence :}

Dr. dr. Agung Putra, M. Si. Med. Candi Prambanan Utara Raya Kav. 1135-1136

Kelurahan Kalipancur, Manyaran, Kecamatan Ngaliyan, Semarang Phone: +628164251646 Email: dr.agungptr@gmail.com ORCID ID: orcid.org/0000-00029822-3119

Date of first submission, April 27, 2018

Date of final revised submission, July 23, 2018

Date of acceptance, July 24, 2018

This open access article is distributed under a Creative Commons AttributionNon Commercial-Share Alike 4.0 International License

Cite this article as: Nugraha A, Putra A. Tumor necrosis factor- $\alpha$-activated mesenchymal stem cells accelerate wound healing through vascular endothelial growth factor regulation in rats. Univ Med 2018;37:135-42. doi: 10.18051/ UnivMed.2018.v37.135-142 


\section{INTRODUCTION}

Wounds are defined as areas of physical or thermal damage in the cutaneous or mucosal epithelium that can be categorized as acute and chronic. ${ }^{(1)}$ The wound healing process consists of the phases of hemostasis, inflammation, proliferation, and remodeling. ${ }^{(2)}$ The inflammatory phase is initiated by neutrophil migration to the wound site as a result of stimulation by various chemoattractant molecules, such as tumor necrosis factor- $\alpha$ (TNF- $\alpha$ ) or interleukin-1 (IL$1)$. The proliferative phase is marked by an increase in a number of growth factors, such as vascular endothelial growth factor (VEGF). ${ }^{(3,4)}$ The increase of these molecules may stimulate fibroblast proliferation that results in increased collagen synthesis, in addition to angiogenesis. ${ }^{(1-}$ 3) Several studies report that mesenchymal stem cells (MSCs) play an important role in wound healing, particularly in the inflammatory phase, because of their immunoregulatory characteristics, so that they are able to control the inflammatory process. ${ }^{(5)}$

Mesenchymal stem cells are adult stem cells with the characteristics of adhering to plastic culture dishes, having various surface markers, such as $\mathrm{CD} 73(+), \mathrm{CD} 90(+), \mathrm{CD} 105(+), \mathrm{CD} 45(-$ ), CD34(-), CD14(-) or CD11 (-), CD79(-) or CD19 (-) and HLA-DR(-), ${ }^{(6)}$ and being able to differentiate into various cells, such as neurons and adipocytes. ${ }^{(6,7)}$ Mesenchymal stem cells also play a role in immunoregulation of inflammation, by suppressing the release of pro-inflammatory molecules from various inflammatory cells, so accelerating the transition from the inflammatory phase into the regenerative phase. ${ }^{(1,8)}$ Several potent pro-inflammatory cytokines, particularly TNF- $\alpha$, play an important role in MSCs activation. ${ }^{(9,10)}$ Activated MSCs release various molecules, such as prostaglandin $\mathrm{E}_{2}\left(\mathrm{PGE}_{2}\right)$ that will bind to their EP4 and EP2 receptors on macrophages, so effecting the polarization of macrophages from the inflammatory into the regenerative type. ${ }^{(11)}$ This is marked by the release of the anti-inflammatory interleukin-10
(IL-10). ${ }^{(12)}$ Specifically, MSCs activation occurs through binding of TNF- $\alpha$ molecules to MSC receptors that impact on the activation of the nuclear factor kappa-B (NF- $\mathrm{kB})$ pathway, so that several anti-inflammatory and proliferative molecules are expressed. ${ }^{(11)}$ Theoretically, the TNF- $\alpha$-activated MSCs are able to express various pro-regenerative growth factors, particularly VEGF, platelet-derived growth factor (PDGF), and fibroblast growth factor (FGF), that can activate fibroblasts and impact on collagen synthesis. ${ }^{(9)}$

Previous studies have reported that MSCs activated by the pro-inflammatory cytokine interferon gamma (IFN- $\gamma$ ) are able to increase wound regeneration and tensile strength that is correlated with the amount of collagen. ${ }^{(13)}$ On the other hand, MSCs that are activated in vitro by TNF- $\alpha$, lipopolysaccharide (LPS) and hypoxia, are able to increase the production of growth factors, particularly VEGF, ${ }^{(14)}$ but the role of TNF- $\alpha$ activated MSCs on VEGF concentrations and their relationship with collagen are as yet unknown. The aim of the present study was to evaluate the effect of MSCs that are activated by TNF- $\alpha$ at a dose of $10 \mathrm{ng} / \mathrm{ml}$ on VEGF and collagen concentrations in rats with incised wounds.

\section{METHODS}

\section{Research design}

This study used a post-test only control group design and was conducted in the Stem Cell and Cancer Research Laboratory, Faculty of Medicine, Universitas Islam Sultan Agung (Unissula), Semarang, from 2 April to 25 August 2017.

\section{Animals}

The subjects of this study were 4 to 6-month old Wistar rats weighing 250-300 grams, that were certified healthy by the Agricultural and Fishery Service (Dinas Pertanian dan Perikanan) of Salatiga City under no. 524.3/0211/421. The sample size calculation was according to the 
Federer formula for determining the required sample size: $(n-1) x(t-1) \geq 15$. The sample used in this study comprised 6 animals per group with an estimated drop-out rate of $10 \%$, so that the total sample size was 24 rats ( $\mathrm{n}=6$ rats/group). The rats were randomly divided into 4 groups (3 intervention groups P1-P3 and 1 control group $\mathrm{K})$. The inclusion criteria were: purebred rats aged 4 to 6 months, weighing 250-300 grams, and without apparent anatomical defects. The exclusion criteria were: not active during the 7day adaptation period and/or having apparent anatomical defects. The drop-out criterion was dying in the course of the experimental interventions. The incised rats were injected with different doses of MSCs. The control group was injected with phosphate buffered saline (PBS). Groups P1, P2, and P3 received subcutaneous injections of activated MSCs at doses of $3 \times 10^{5}$, $6 \times 10^{5}$ and $12 \times 10^{5}$ cells, respectively. The interventions were applied once daily in the morning.

\section{Surgical procedure}

Paravertebral full-thickness dorsal skin incisions were made aseptically with a No. 15 scalpel (B. Braun Aesculap AG, Tuttlingen, Germany) under general anesthesia in the longitudinal axis at least $1 \mathrm{~cm}$ apart and perpendicular to the skin cleavage lines. As a result, minimal strain was applied to the skin, allowing for direct visual control of the depth of the incision. For each incision, the dorsal muscles were the limits at which to stop. ${ }^{(15)}$

\section{Isolation of MSCs}

The umbilical cord of a female rat at 19 days of pregnancy was washed in PBS. The umbilical blood vessels were removed, then the umbilicus was cut into lengths of 2-5 mm using a sterile knife and the sections distributed evenly on a $66-\mathrm{mm}$ culture dish. The medium used was Dulbecco's modified Eagle's medium (DMEM) (Sigma-Aldrich, St. Louis, MO) mixed with 10\% PBS, $100 \mathrm{IU} / \mathrm{ml}$ penicillin/streptomycin (GIBCO, Invitrogen), then incubated at $37^{\circ} \mathrm{C}$ with $5 \%$
$\mathrm{CO}_{2}$. The medium was refreshed once in 3 days. ${ }^{(16)}$

\section{Characteristics of the MSC phenotype}

The expression of the MSCs isolated from the umbilical cord of the female rat was evaluated by immunocytochemistry using MSC-positive markers. After the MSCs were $60-80 \%$ confluent, they were harvested and grown on coverslips, then fixed with $4 \%$ paraformaldehyde in $90 \%$ ethanol for 15 minutes at $4^{\circ} \mathrm{C}$. The cells were incubated with $\mathrm{CD} 73$ and CD105 primary antibody as MSC-positive markers (1:100; BD Pharmingen, San Diego, CA, USA) for 60 minutes at room temperature, washed in PBS for 10 minutes then secondary antibody $(1: 2500)$ was added, the cells left to stand for 15 minutes at room temperature, then counterstained with diaminobenzene (DAB) (Santa Cruz Biotech) and observed under the microscope. ${ }^{(16)}$

\section{In-vitro differentiation}

The mesenchymal stem cells were grown in culture dishes at densities of $5 \times 10^{3}$ and $1 \times 10^{4}$ cells/well, to which was added osteogenic induction medium containing $10 \mathrm{mmol} / \mathrm{L} \beta$ glycerophosphate, $10^{-7} \mathrm{~mol} / \mathrm{L} / 0.1 \mu \mathrm{M}$ dexamethasone, $50 \mu \mathrm{mol} / \mathrm{L}$ ascorbate-2-phosphate (Sigma-Aldrich, Louis St, MO) and $10 \%$ fetal bovine serum (FBS) in DMEM. Osteogenic differentiation was observed by Alizarin Red staining after 21 days of induction to find calcium deposits. The cells were rinsed in PBS and fixed with cold $70 \%$ ethanol (v/v) for 1 hour at room temperature, then rinsed three times with twicedistilled water. A volume of $1 \mathrm{ml} \%$ Alizarin Red solution (w/v) ( $\mathrm{pH} 4.1-4.3)$ was added and the cells incubated for 30 minutes at room temperature, then rinsed four times in twicedistilled water. ${ }^{(17)}$

\section{TNF- $\alpha$ induction of MSCs}

MSCs ( $1 \times 10^{4}$ cells/well) were supplemented with $10 \mathrm{ng} / \mathrm{ml}$ recombinant TNF- $\alpha$ (BioLegend, San Diego, CA) on a 24-well plate using alphaMEM medium (Sigma-Aldrich, Louis St, 
$\mathrm{MO}$ ), then incubated for 24 hours at $37^{\circ}$ with $5 \%$ $\mathrm{CO}_{2}$.

\section{Rat VEGF ELISA assay}

The serum VEGF assay by means of an ELISA kit (Fine test, China) was performed at room temperature according to the manufacturer's instructions. The ELISA plate was coated with capture antibody and incubated overnight at $4^{\circ} \mathrm{C}$. The wells were washed, then blocked for 1 hour, after which they were incubated with rat VEGF standard solution and the intervention and control rat sera for 2 hours, then diluted to 1:100 so that the VEGF concentrations could be determined on the standard curves. After washing, the wells were incubated with detection antibody for one hour, then washed again several times. The wells were incubated with Avidin-HRP for 30 minutes, washed thoroughly, and incubated with substrate solution for 15 minutes, which was followed by the addition of the stop solution. The results were analyzed at a wavelength of $450 \AA$ using a microplate reader. The VEGF concentrations (pg/ $\mathrm{ml}$ ) were measured on days 3 and 5 of the experiment.

\section{Preparation of collagen slides}

Skin tissue was collected and placed in $10 \%$ neutral-buffered formalin then embedded in paraffin or Histogel (Thermo Scientific, Watham, MA, USA). Subsequently the tissue paraffin block was cut on a microtome to a thickness of 5-10 $\mu \mathrm{m}$ then stained with Masson Trichrome and observed under the microscope. The collagen density was calculated from the area of the collagenous tissue formed on each slide (\%).

\section{Statistical analysis}

The amount of collagen and the VEGF concentration were presented descriptively. Data processing was performed using SPSS 23.0 for Windows. The test of normality used the ShapiroWilk test and the test of homogeneity used Levene's statistical test. Subsequently a parametric difference test was performed followed by ANOVA and LSD post-hoc test.

\section{Ethical clearance}

All research activities were in accordance to and approved by the Commission on Test Animal Ethics (Komisi Etik Hewan Uji), Faculty of Medicine, Universitas Islam Sultan Agung, Semarang, under No. 204/VI/2017/Komisi Bioetik.

\section{RESULTS}

\section{Characteristics of MSCs}

The characteristics of the MSCs isolated by in-vitro dish culture until the cell population was at $80 \%$ confluence were as follows. The cells were spindle-shaped, resembling fibroblasts (Figure 1a). The confluent MSCs that were tested using an immunocytochemical technique showed positive expression of various protein surface markers, particularly CD105(+) (Figure 1b) and CD73(+) (Figure 1c), as indicated by the development of a brown color in the population of MSCs. Tests for differentiating the MSCs were
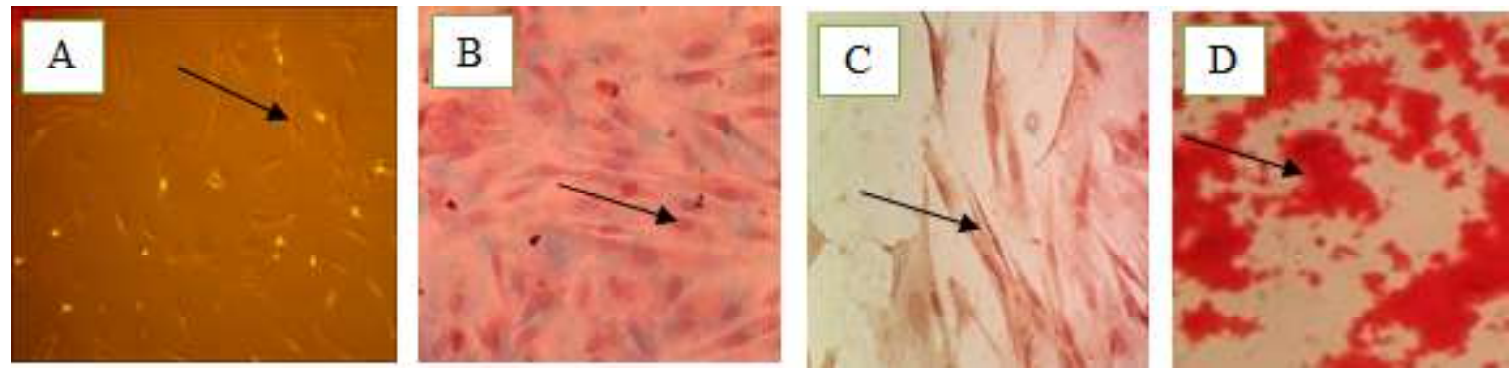

Figure 1. Characteristics and differentiation of cultured mesenchymal stem cells

Legend: (a) Umbilical cord candidate MSCs from in-vitro culture (b) CD105 expression, (c) CD73 expression. MSCs are brownish in color (d) Osteogenic differentiation with Alizarin Red staining 
Table 1. Mean VEGF concentration on days 3 and 5 and collagen density on day 7

\begin{tabular}{|c|c|c|c|c|c|}
\hline \multirow{2}{*}{ Day } & \multicolumn{4}{|c|}{ Intervention group (mean \pm SD) } & \multirow{2}{*}{ p value } \\
\hline & Control $(n=6)$ & $P 1(n=6)$ & $P 2(n=6)$ & P3 $(n=6)$ & \\
\hline $\begin{array}{c}\text { VEGF } \\
\text { on day } 3(\mathrm{pg} / \mathrm{mL})\end{array}$ & $29.17 \pm 11.67$ & $87.38 \pm 17.38$ & $112.99 \pm 19.91$ & $98.52 \pm 43.88$ & 0.001 \\
\hline $\begin{array}{c}\text { VEGF } \\
\text { on day } 5(\mathrm{pg} / \mathrm{mL})\end{array}$ & $67.45 \pm 53.65$ & $5.09 \pm 3.42$ & $22.05 \pm 8.23$ & $15.93 \pm 34.49$ & 0.012 \\
\hline $\begin{array}{c}\text { Collagen } \\
\text { on day } 7(\%)\end{array}$ & $1.33 \pm 0.51$ & $1.50 \pm 0.54$ & $2.50 \pm 0.54$ & $2.83 \pm 0.80$ & 0.000 \\
\hline
\end{tabular}

*Significant at $\mathrm{p}<0.05$; Note: P1: activated MSCs at dose of 3x $10^{5}$ cells; P2: activated MSCs at dose of $6 \times 10^{5}$ cells; P3: activated MSCs at dose of $12 \times 10^{5}$ cells

performed by administration of osteogenic medium and showed that MSCs were capable of differentiating into osteogenic cells, as indicated in the cell population by a red color from Alizarin Red staining (Figure 1d).

\section{VEGF concentration and collagen density}

The mean VEGF concentration increased on day 3 , then decreased on day 5 . The VEGF concentration on day 3 showed a significant increase $(\mathrm{p}<0.05)$ (Table 1) with the following mean values: $\mathrm{K}=29.17 \pm 11.67 \mathrm{pg} / \mathrm{mL} ; \mathrm{P} 1=$ $87.38 \pm 17.38 \mathrm{pg} / \mathrm{mL} ; \mathrm{P} 2=112.99 \pm 19.91 \mathrm{pg} / \mathrm{mL}$; P $3=98.52 \pm 43.88 \mathrm{pg} / \mathrm{mL}$. However, on day $5 \mathrm{a}$ non significant decreased was found $(\mathrm{p}>0.05)$ (Table 1).

The mean collagen density on day 7 differed significantly between the control group and the intervention groups $(p<0.05)$. Mean collagen density was highest in group P3 $(2.83 \pm 0.80)$ and lowest in the control group, group $\mathrm{P} 1$, and group P2 $(1.33 \pm 0.51,1.50 \pm 0.54$, and $2.50 \pm$ 0.54 , respectively) (Table 1$)$. These results were also supported by the microscopic picture of collagen preparations with Masson Trichrome staining. The collagen was colored blue and filled the field of view (Figure 2).

The results of the post-hoc analysis showed that mean VEGF concentration on days 3 and 5 differed significantly between the control group and groups P1, P2 and P3 ( $<<0.05)$. However, mean VEGF concentration on days 3 and 5 showed no significant difference between groups P1, P2 and P3 (Table 2). Mean collagen density on day 7 differed significantly between the control group and groups $\mathrm{P} 1$ and $\mathrm{P} 2$, between groups $\mathrm{P} 1$ and $\mathrm{P} 3$, and between groups $\mathrm{P} 2$ and P3.

\section{DISCUSSION}

Our study results showed that serum VEGF concentration increased significantly on day 3 in rat wounds treated with TNF- $\alpha$ activated MSCs, giving the impression that MSCs are able to accelerate the transition from the inflammatory phase into the proliferative phase through the polarization of type M1 proinflammatory
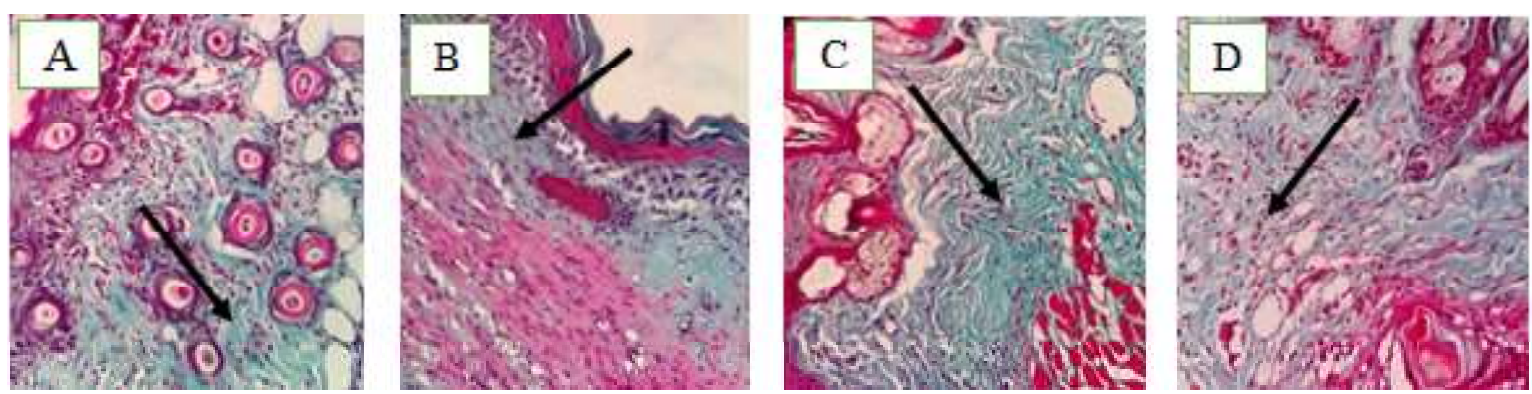

Figure 2. Microscopic preparations showing collagen density, with Masson trichrome staining. Collagen is bluish in color. Magnification 100x

Legend : Panels A,B, C and D represent controls, P1, P2 and P3, respectively 
Table 2. Post-hoc test for VEGF on days 3 and 5 and collagen on day 7

\begin{tabular}{|c|c|c|c|}
\hline & & $\begin{array}{c}\begin{array}{c}\text { Mean } \\
\text { difference }\end{array} \\
\end{array}$ & $\begin{array}{c}\mathbf{p} \\
\text { value }\end{array}$ \\
\hline \multicolumn{4}{|c|}{ VEGF on day 3} \\
\hline \multirow[t]{3}{*}{ Controls } & $\mathbf{P 1}$ & 62.36 & $0.002 *$ \\
\hline & $\mathbf{P 2}$ & 45.40 & $0.018 *$ \\
\hline & P3 & 51.51 & $0.009 *$ \\
\hline \multirow[t]{2}{*}{ P1 } & $\mathbf{P 2}$ & 16.96 & 0.339 \\
\hline & P3 & 10.848 & 0.587 \\
\hline $\mathbf{P 2}$ & P3 & 6.114 & 0.727 \\
\hline \multicolumn{4}{|c|}{ VEGF on day 5} \\
\hline \multirow[t]{3}{*}{ Controls } & $\mathbf{P 1}$ & 57.21 & $0.003 *$ \\
\hline & $\mathbf{P 2}$ & 82.82 & $0.000 *$ \\
\hline & P3 & 68.35 & $0.001 *$ \\
\hline \multirow[t]{2}{*}{ P1 } & P2 & 25.61 & 0.144 \\
\hline & P3 & 11.13 & 0.513 \\
\hline $\mathbf{P 2}$ & P3 & 14.47 & 0.398 \\
\hline \multicolumn{4}{|c|}{ Collagen on day 7} \\
\hline \multirow[t]{3}{*}{ Controls } & P1 & 1.00 & $0.003 *$ \\
\hline & $\mathbf{P 2}$ & 1.33 & $0.000 *$ \\
\hline & P3 & 0.16 & 0.576 \\
\hline \multirow[t]{2}{*}{ P1 } & P2 & 0.33 & 0.269 \\
\hline & P3 & 0.16 & $0.001 *$ \\
\hline P2 & P3 & 1.500 & $0.000 *$ \\
\hline
\end{tabular}

*Significant at $\mathrm{p}<0.05$; Note : P1 : activated MSCs at dose of $3 \times 10^{5}$ cells; P2 : activated MSCs at dose of $6 \times 10^{5}$ cells; P3 : activated MSCs at dose of $12 \times 10^{5}$ cells

macrophages into type M2 proliferative macrophages. ${ }^{(18)}$ This is in line with previous studies stating that MSCs activated by $50 \mathrm{ng} / \mathrm{ml}$ of TNF- $\alpha$ are able to increase VEGF expression significantly in 24 hours post-induction, ${ }^{(14)}$ indicating that the MSCs are induced by the TNF- $\alpha$ inflammatory signals to secrete proliferative molecules, such as VEGF, in addition to anti-inflammatory molecules. ${ }^{(19)}$ Other studies have reported that in normal wound healing the serum VEGF concentration starts to increase on the fourth day and continues until the seventh day of the proliferative phase. $^{(1,20)}$ This gives the impression that activated MSCs are more potent in suppressing inflammation in wounds and promote the activation of various pro-proliferative cells, so accelerating the wound healing process.

On the other hand, our study also found that the VEGF concentration decreased significantly on day $5(\mathrm{p}<0.05)$. We surmise that this decrease in VEGF concentration on day 5 was due to the more rapid transition from the proliferative to the remodeling phase, as a result of the administration of TNF- $\alpha$-activated MSCs. This agrees with previous studies stating that in the remodeling phase the VEGF concentration decreases significantly, marking the end of the proliferative phase. ${ }^{(21)}$ A high VEGF concentration in the remodeling phase may cause an interference with wound healing that is marked by tissue fibrosis. ${ }^{(22)}$

Our study also found a significantly increased collagen density in wounds receiving TNF- $\alpha$-activated MSCs. The collagen density is shown by the microscopic picture of a bluish color in preparations with Masson's trichrome staining. This collagen density correlates with the number of TNF- $\alpha$-activated MSCs administered at each of the interventions. These results are supported by previous studies, in that MSC administration is able to accelerate wound regeneration by modulating collagen synthesis, in addition to inhibiting apoptosis. ${ }^{(23)}$ We think that the increase in collagen density on day 7 is related to the ability of TNF- $\alpha$-activated MSCs for paracrine expression of various growth factors, such as VEGF, so accelerating the transition from the inflammatory to the proliferative phase, in addition to differentiating into fibroblasts and activating endogenous stem cells to promote fibroblast formation and collagen synthesis. This agrees with previous studies stating that fibroblasts that express large amounts of VEGF may trigger collagen formation. ${ }^{(24)}$

One limitation of the present study is that we did not determine the concentrations of PDGF and transforming growth factor (TGF) that are potent mediators of fibroblast activation in collagen synthesis. We also did not measure VEGF concentrations at baseline and at the end of the interventions to determine their relationship with the inflammatory and remodeling phases. This study has the potential to become in the future one of the solutions to the problem of accelerating wound healing, particularly chronic wounds. 


\section{CONCLUSION}

This study demonstrated that TNF- $\alpha$ activated MSCs are able to regulate VEGF concentrations and collagen density in wound healing. The VEGF concentrations expressed by activated MSCs accelerate the transition from the inflammatory to the regenerative phase and trigger collagen synthesis in wound healing.

\section{CONFLICT OF INTEREST}

Competing interests: no relevant disclosures

\section{FINANCIAL DISCLOSURE}

The authors did not receive any specific grant from any public funding agency.

\section{ACKNOWLEDGEMENT}

We would like to express our heartfelt gratitude to the staff members of the Stem Cell and Cancer Research Laboratory (SCCR), Faculty of Medicine, Universitas Islam Sultan Agung, Semarang and the Postgraduate Biomedical Program, Faculty of Medicine, Universitas Islam Sultan Agung, for their assistance in this study.

\section{REFERENCES}

1. Landen NX, Li D, Stahle M. Transition from inflammation to proliferation: a critical step during wound healing. Cell Mol Life Sci 2016;73:386185. doi: 10.1007/s00018-016-2268-0.

2. Nuschke A. Activity of mesenchymal stem cells in therapies for chronic skin wound healing. Organogenesis 2014;10:29-37. doi: 10.4161/org. 27405.

3. Reinke JM, Sorg H. Wound repair and regeneration. Eur Surg Res 2012;49:35-43.

4. Eming SA, Krieg T, Davidson JM. Inflammation in wound repair: Molecular and cellular mechanisms. J Invest Dermatol 2007;127:514-25. doi: 10.1038/sj.jid.5700701.

5. Castro-Manrreza ME, Montesinos JJ. Immunoregulation by mesenchymal stem cells: biological aspects and clinical applications. J
Immunol Res 2015;2015:1-20. doi: 10.1155/2015/ 394917.

6. Dominici M, Le Blanc K, Mueller I, et al. Minimal criteria for defining multipotent mesenchymal stromal cells. The International Society for Cellular Therapy position statement. Cytotherapy 2006;8: 315-7. doi: 10.1080/14653240600855905.

7. Ding DC, Shyu WC, Lin SZ. Mesenchymal stem cells. Cell Transplant 2011;20:5-14. doi: 10.3727/ 096368910X.

8. Prockop DJ, Youn Oh J. Mesenchymal stem/ stromal cells (MSCs): role as guardians of inflammation. Mol Ther 2012;20:14-20. doi: 10.1038/mt.2011.211/nature06264.

9. Kwon YW, Heo SC, Jeong GO, et al. Tumor necrosis factor- $\alpha$-activated mesenchymal stem cells promote endothelial progenitor cell homing and angiogenesis. Biochim Biophys Acta - Mol Basis Dis 2013;1832:2136-44. doi: 10.1016/j.bbadis. 2013.08.002.

10. Sabio G, Davis RJ. TNF and MAP kinase signaling pathways. Semin Immunol 2014;26:237-45. doi: 10.1016/j.smim.2014.02.009.

11. Gordon S, Martinez FO. Alternative activation of macrophages: mechanism and functions. Immunity 2010;32:593-604. doi: 10.1016/j.immuni. 2010.05.007.

12. Nauta AJ, Fibbe WE. Immunomodulatory properties of mesenchymal stromal cells. Blood 2007 110:3499-506. DOI: https://doi.org/10.1182/ blood-2007-02-069716,9-506.

13. Lee S, Szilagyi E, Chen L, et al. Activated mesenchymal stem cells increase wound tensile strength in aged mouse model via macrophages. J Surg Res 2013;181:20-4. doi:10.1016/j.jss.2012. 05.040 .

14. Crisostomo PR, Wang Y, Markel TA, et al. Human mesenchymal stem cells stimulated by $\mathrm{TNF}-\alpha$, LPS, or hypoxia produce growth factors by an NFKB- but not JNK-dependent mechanism. AJP Cell Physiol 2008;294:C675-82. doi :10.1152/ ajpcell.00437.2007.

15. Maxson S, Lopez EA, Yoo D, DanilkovitchMiagkova A, LeRoux MA. Concise review: role of mesenchymal stem cells in wound repair. Stem Cells Transl Med 2012;1:142-9. doi: 10.5966/ sctm.2011-0018.

16. Putra A, Rahmalita A, Tarra Y, et al. The effect of mesenchymal stem cells on the endothelial cells of diabetic mice. In: Proceedings of the 4th Bandung International Biomolecular Medicine Conference (BIBMC) and the $2^{\text {nd }}$ Asean Congress on Medical Biotechnology and Molecular Biosciences (ACMM), Bandung, West Java, Indonesia, 4-6 October 2016.p.57-60. 
17. Deshpande S, James AW, Blougha J, et al. Reconciling the effects of inflammatory cytokines on mesenchymal cell osteogenic differentiation. J Surg Res 2013;185:278-85. doi: 10.1016/j.jss.2013. 06.063 .

18. Bernardo ME, Fibbe WE. Review mesenchymal stromal cells: sensors and switchers of inflammation. Stem Cell 2013;13:392-402. doi: 10.1016/j.stem.2013.09.006.

19. Prockop DJ. Modulation of the process by mesenchymal stem/stromal cells. Matrix Biol 2016;51:7-13. doi: 10.1016/j.matbio.2016.01.010.

20. Liang Y, Brekken RA, Hyder SM. Vascular endothelial growth factor induces proliferation of breast cancer cells and inhibits the antiproliferative activity of anti-hormones. Endocr Relat Cancer 2006;13:905-19.
21. Bao P, Kodra A, Tomic-Canic M, et al. J Surg Res 2009;153:347-58. doi: 10.1016/j.jss.2008.04.023.

22. Barron L, Wynn TA. Fibrosis is regulated by Th2 and Th17 responses and by dynamic interactions between fibroblasts and macrophages. Am J Physiol Gastrointest Liver Physiol 2011;300:G7238. doi: 10.1152/ajpgi.00414.2010.

23. Wright EJ, Hodson NW, Sherratt MJ, et al. Combined MSC and GLP-1 therapy modulates collagen remodeling and apoptosis following myocardial infarction. Stem Cells Int 2016;2016. Article ID 7357096, 12 pages. http://dx.doi.org/ 10.1155/2016/7357096.

24. Bauer SM, Bauer RJ, Liu ZJ, et al. Vascular endothelial growth factor-C promotes vasculogenesis, angiogenesis, and collagen constriction in three-dimensional collagen gels. J Vasc Surg 2005;41:699-707. 